\title{
Neuropharmacological activity of nut grass (Cyperus Rotundus L.) rhizome fraction
}

\author{
Lusi Putri Dwita*, Ema Dewanti, Vera Ladeska, Sediarso, \\ Adnan Munthasir Ulfa Safni, Rahma Wulan Sari \\ Universitas Muhammadiyah Prof. DR. HAMKA (UHAMKA), Fakultas Farmasi dan Sains \\ Jl. Delima II/IV Perumnas Klender Jakarta Timur
}

\begin{abstract}
The flavonoids content of Cyperus rotundus rhizomes is presumed to show activities on a central nervous system involving GABAergik. This research aimed to further investigate the neuropharmacological properties of Cyperus rotundus rhizomes fraction by measuring their hypnotic-sedative and anticonvulsant activities. The exploratory behavior test was performed using the hole-board method, while the motor coordination was assessed using the rotarod test. The results showed that the $70 \%$ ethanol fraction of Cyperus rotundus rhizome exhibited significant neuropharmacological activities $(\mathrm{p}<0.05)$. Among the three fractions tested in this research (i.e., ethanol, ethyl acetate, and n-hexane), the ethanol fraction showed the best hypnotic-sedative and anticonvulsant activities. The ethanol fraction of Cyperus rotundus rhizome could shorten the duration of HLE equal to sodium valproate and potentiate phenobarbital-induced sleep by reducing the onset and prolonging the duration of sleep. The highest dose of the $70 \%$ ethanol fraction of Cyperus rotundus rhizome $(356.7 \mathrm{mg} / \mathrm{kg})$ displayed the best anxiolytic activity, resembling that of diazepam ( $p>0.05)$. In conclusion, Cyperus rotundus rhizome appeared as potent neuropharmacological drug candidate with abilities comparable to synthetic drugs.
\end{abstract}

Keywords: hypnotic, anxiolytics, anticonvulsant, Cyperus rotundus, rhizome

*Corresponding author:

Lusi Putri Dwita

Fakultas Farmasi dan Sains, Universitas Muhammadiyah Prof. DR. HAMKA

Jl. Delima II/IV Perumnas Klender, Jakarta Timur

Email: lusi_putridwita@uhamka.ac.id 


\section{INTRODUCTION}

Drugs that work on the central nervous system (CNS) are the most widely used pharmacological agents by the public (Katzung and Trevor, 2015). These drugs have many therapeutic benefits, for instance, it relieves pain, fever, and pressing movement disorders, induces sleep or arousal, reduces appetite, and eases nausea. Some of CNS drugs overcome anxiety, depression, mania, and schizophrenia (Brunton et al., 2013).

Cyperus rotundus has various benefits as medicine. Ahmad et al., (2014) showed that the ethanol extract of Cyperus rotundus rhizome can inhibit inflammation, reduce gastric lesions, and introduce sedation effects in mice. Other research also attests to the anticonvulsant activity of this extract following its administration to rat at a dose of $500 \mathrm{mg} / \mathrm{kg}$ (Biradar et al., 2010).

This research analyzed the fraction of the $70 \%$ ethanol extract of Cyperus rotundus rhizome. The fractions included 70\% ethanol, ethyl acetate, and n-hexane. Phytochemical study on Cyperus rotundus rhizome has identified the presence of alkaloids, flavonoids, tannins, glycosides, saponins, starch, essential oil, and sesquiterpene (Yudistyawan, 2013). Cyperus rotundus rhizome mostly contains quercetin (Krishna and Renu, 2013). This research aimed to test the effects of the $70 \%$ ethanol, ethyl acetate, and n-hexane fractions of Cyperus rotundus rhizome on the central nervous system.

\section{MATERIALS AND METHODS Materials}

The materials used in the research were collected from the Research Institute for Spices and Medicinal Plants (BALITTRO) Bogor and determined by the Herbarium Bogoriense of Indonesian Institute of Sciences (LIPI). Healthy Balb-c male mice weighing 20-30 g and Sprague Dawley male rats weighing 200-250 g were used in this research. This study has been approved by the Committee of Ethics of Health Research, Faculty of Medicine, University of Indonesia with the approval number of 699/UN2.F1/ETHICS/2017 and 726/UN2.F1/ETIK/2017.

\section{Methods}

\section{Extraction and fractionation}

Rhizome powder $(2 \mathrm{~kg})$ was soaked in $70 \%$ ethanol and left for 24 hours. This process was repeated 3 times with fresh solvent. The filtrate was evaporated using the Rotary Evaporator Vacuum. The extract was then partitioned into ethanol, ethyl acetate, and n-hexane fraction.

\section{Maximal electroshock (MES)-induced convulsion in rats}

The anticonvulsant property of the drug in this model was assessed by its ability to protect against MES-induced convulsions. The rats were divided into 5 groups; each of which consisted of 5 rats. Group 1 was given $1.54 \mathrm{mg} / \mathrm{kg}$ of valproic acid, while group 2 was treated with Na-CMC Groups 3, 4, and 5 were administered with $178.3 \mathrm{mg} / \mathrm{kg}$ of the $70 \%$ ethanol, ethyl acetate, and $\mathrm{n}$ hexane fractions of Cyperus rotundus rhizome. Maximal electroshock of $150 \mathrm{mAmp}$ and 50 hertz for 0.2 seconds was applied through ear clip electrodes to induce convulsion. The parameters observed in this test were the time elapsed between the induction and the onset of HLE, the duration of HLE, and the mortality of the tested animals over 24 hours. A preliminary screening test was conducted to include only rats that had shown HLE in this experimental model. The experimental drugs were administered one hour before the electrical shock (Mudium and Kolasani, 2014; Biradar et al., 2010). The test was considered positive if the animal exhibited tonic extensor seizure with rearward HLE, i.e., when the angle to the body exceeded $90^{\circ}$, and sustained for more than $3 \mathrm{~s}$ following $10 \mathrm{~s}$ after stimulation (Castel-Branco et al., 2009). 


\section{Phenobarbital-induced sleeping test}

This method observed the onset of sleep and sleep duration on BALB/C mice (weight $=25$ 30 grams, age $=2-3$ months old). These mice were divided into 5 groups: group 1 (normal control) was treated with $\mathrm{Na}-\mathrm{CMC}$, group 2 (negative control) was treated with $\mathrm{Na}-\mathrm{CMC}$ and $41.1 \mathrm{mg} / \mathrm{kg}$ of phenobarbital, and groups 3,4,5 were administered with the $70 \%$ ethanol, ethyl acetate, and nhexane fractions of Cyperus rotundus rhizome at the same dose of $356.6 \mathrm{mg} / \mathrm{kg}$. Except for the normal controls, all groups were induced by phenobarbital $(41.1 \mathrm{mg} / \mathrm{kg}$ i.m.) 45 minutes after the oral administration of test substance. Sleeping time was considered to be the time interval between the disappearance and reappearance of the righting reflex. The prolongation of sleeping time was expressed in a percentage using the following ratio (Du et al., 2002; Chouksey et al., 2013):

$$
\text { Prolongation of sleep duration }(\%)=\frac{\text { The total sleeping time of treated animal }}{\text { The total sleeping time of control animal }} \times 100 \%
$$

\section{Hole-board Test}

The hole-board test aimed to study the exploratory behavior of the test animal. The holeboard apparatus (Infrared Actimeter Orchid Scientific $($ ) is a box $(28 \times 28 \times 20.5 \mathrm{~cm})$ consisting of 16 equidistant holes with a diameter of $3 \mathrm{~cm}$; the floor and the walls of the box were constructed from transparent Plexiglas. Infrared at the base of the hole detected the number of head-dipping. At the beginning of the test, mice were allowed to explore the apparatus freely for 10 minutes. Soon after administering the test substance, the exploration activities were recorded based on the number of head-dipping within 60 minutes (Arenas et al., 2014; Doukkali et al., 2015; Ajao and Akindele, 2013).

\section{Rotarod test}

The effects of the test substance on motor coordination were identified using a rotarod. This apparatus consisted of a base platform and an iron rod (diameter $=3 \mathrm{~cm}$; length $=30 \mathrm{~cm}$ ) with a non-slippery surface. Twenty-four hours before the test, the animals were pre-selected in a training session based on their ability to remain on the bar (at $12 \mathrm{rpm}$ ) for 2 minutes. After the administration of the test substance, the mice were positioned on the bar (at $30 \mathrm{rpm}$ ). Previously, the mice were allowed to run on the rotarod for 5 minutes to allow for familiarity with the equipment. The time spent in the apparatus was observed for 30 minutes. The apparatus was cleaned thoroughly between trials with alcohol. All behavioral recordings were carried out by an observer who was blind to the treatment the mice had received (Doukkali et al., 2015).

\section{Data Analysis}

The data were analyzed statistically using One-way Analysis of Variance (ANOVA), followed by the Tukey-Kramer Post Hoc test for multiple comparisons. P $<0.05$ was considered to represent a statistical significance. The results were presented in tables.

\section{RESULTS AND DISCUSSION}

This research aimed to identify the activities of Cyperus rotundus rhizome on the central nervous system. It used several methods, namely phenobarbital-induced sleeping test, maximal electroshock (MES)-induced convulsion, hole board, and rotarod tests. MES-induced convulsion model was used for generalized tonic-clonic seizures. MES causes cellular damage by facilitating the entry of $\mathrm{Ca} 2+$ into the cells in large amounts, prolonging the duration of convulsions. It also promotes the entry of other positive ions like $\mathrm{Na}^{+}$, the blockade of which can prevent MES-induced tonic extension (Venkatanarayana et al., 2013). The electrical seizures were induced by an electroconvulsiometer in which test animals were subjected to non-lethal electric shock using a set 
of electrodes applied to ear pinna or cornea (Mudium and Kolasani, 2014). The time elapsed from the shock deliverance to the onset of tonic limb extension was prolonged by the $70 \%$ ethanol, ethyl acetate, and n-hexane fractions of Cyperus rotundus (CR) significantly though incomparable to sodium valproate (Table I). There was also a significant reduction in the duration of HLE with both sodium valproate and the CR fraction. However, the $70 \%$ ethanol was the only CR fractions that shortened the duration of HLE as much as sodium valproate. There was no mortality from both CR fraction- and sodium valproate-treated rat groups for over 24 hours.

Table I. The exhibited anticonvulsants activity of the $70 \%$ fraction of Cyperus rotundus in the MES-induced convulsion test

\begin{tabular}{|c|c|c|}
\hline Groups & The Onset of HLE (seconds) & $\begin{array}{c}\text { The Duration of HLE } \\
\text { (seconds) }\end{array}$ \\
\hline $\begin{array}{llll}\text { Valproic } & \text { acid } & (1.54 & \mathrm{mg} / \mathrm{kg} \\
\text { BW }) & & & \\
\end{array}$ & $19.8 \pm 2.58^{\mathrm{a}}$ & $23.8 \pm 2.28^{\mathrm{a}}$ \\
\hline $\mathrm{CMC}-\mathrm{Na}$ & $0 \pm 0^{\mathrm{b}}$ & $65.6 \pm 5.54^{\mathrm{b}}$ \\
\hline $\begin{array}{l}\text { CR } 70 \% \text { ethanol fraction } \\
(178.3 \mathrm{mg} / \mathrm{kg} \mathrm{BW})\end{array}$ & $15.2 \pm 1.64^{\mathrm{ab}}$ & $30.2 \pm 3.03^{\mathrm{a}}$ \\
\hline $\begin{array}{l}\text { CR ethyl acetate fraction } \\
(178.3 \mathrm{mg} / \mathrm{kg} \mathrm{BW})\end{array}$ & $5.2 \pm 1.30^{\mathrm{ab}}$ & $35.0 \pm 3.67^{\mathrm{ab}}$ \\
\hline $\begin{array}{l}\text { CR n-hexane fraction }(178.3 \\
\mathrm{mg} / \mathrm{kg} \mathrm{BW})\end{array}$ & $3.4 \pm 2.19^{\mathrm{ab}}$ & $45.6 \pm 4.44^{\mathrm{ab}}$ \\
\hline
\end{tabular}

All CR fractions were able to prolong the duration of sleep incomparable to Na-CMC (negative control). However, only the 70\% ethanol fraction of Cyperus rotundus rhizome showed a significantly faster onset of sleep $(\mathrm{p}<0.05)$. This fraction also had the highest percentage of prolonged sleep duration, which increased by $182 \%$ compared to the negative control group (Table II). Phenobarbital exerts its pharmacological effect by binding to specific GABA-A receptor subunits at CNS neuronal synapses and facilitating the opening duration of GABA-mediated chloride ion channel; hence the enhanced membrane hyperpolarization (Katzung and Trevor, 2015). Phenobarbital-induced sleeping time test was used to evaluate the possible sedativehypnotic effects of the Cyperus rotundus rhizome fraction. The fraction that extends the duration of phenobarbital-induced sleeping time is deemed a hypnotic agent. The ethanol CR fraction potentiated the phenobarbital-induced sleep by decreasing the onset and prolonging the duration of sleep, which were considered to be the two aspects of a hypnotic effect.

The hole-board test aimed to study the exploratory behavior of the animal (Arenas et al., 2014). When placed in a foreign environment, animals are expected to experience anxiety. Therefore, the anxiolytic activity can be determined by the decline of the exploratory behavior of a test animal. The parameter observed as exploratory behavior was head-dipping (i.e., test animals entered their heads into the hole). The anxiety in the test animals was characterized by an increase in the number of head-dipping (Brown and Nemes, 2008). The study has shown that the ethanol extract of the nut grass (Cyperus rotundus) rhizome at a dose of $500 \mathrm{mg} / \mathrm{kg}$ BW exhibits neuropharmacology activity, as demonstrated by a decrease in the activity of the central nervous system. However, the decline in exploratory activity at this dose is not yet comparable to diazepam (Ahmad et al., 2014). This research showed that ethanol fraction of CR in all doses caused a calming effect and reduced anxiety, as indicated by a significant decrease in the number of headdipping (Table III).

Pharmaciana Vol. 8, No. 2, Nov 2018, Page. 217 - 224 
Table II. The exhibited hypnotic activity of the Cyperus rotundus rhizome fractions in the phenobarbital-induced sleeping time test

\begin{tabular}{|c|c|c|c|}
\hline Groups & $\begin{array}{c}\text { Sleep Onset } \\
\text { (minutes) }\end{array}$ & $\begin{array}{l}\text { Sleep Duration } \\
\text { (minutes) }\end{array}$ & $\begin{array}{c}\text { Prolongation of } \\
\text { sleep duration } \\
(\%)\end{array}$ \\
\hline $\begin{array}{ll}\text { CMC-Na } & + \\
\text { phenobarbital } & \end{array}$ & $26 \pm 0.89$ & $200 \pm 6.03$ & - \\
\hline $\begin{array}{l}\text { CR } 70 \% \text { ethanol fraction } \\
(356.6 \mathrm{mg} / \mathrm{kg} \quad \mathrm{BW})+ \\
\text { phenobarbital }\end{array}$ & $15 \pm 3.52^{\mathrm{a}}$ & $364 \pm 8.22^{\mathrm{a}}$ & 182 \\
\hline $\begin{array}{l}\text { CR Ethyl acetate } \\
\text { fraction (356.6 } \mathrm{mg} / \mathrm{kg} \\
\mathrm{BW})+ \text { phenobarbital }\end{array}$ & $22 \pm 1.89$ & $226 \pm 11.09^{\mathrm{a}}$ & 113 \\
\hline $\begin{array}{l}\text { CR n-hexane fraction } \\
(356.6 \mathrm{mg} / \mathrm{kg} \text { BW })+ \\
\text { phenobarbital }\end{array}$ & $24 \pm 2.52$ & $214.8 \pm 3.76^{\mathrm{a}}$ & 107.4 \\
\hline
\end{tabular}

Table III. The exhibited anxiolytic activity in the hole-board and rotarod tests

\begin{tabular}{|c|c|c|}
\hline Group & $\begin{array}{l}\text { The total number } \\
\text { of head-dipping }\end{array}$ & $\begin{array}{l}\text { Time hangings on rotarod } \\
\text { without falling in } 30 \text { minutes } \\
\text { (seconds) }\end{array}$ \\
\hline Diazepam $0.82 \mathrm{mg} / \mathrm{kg}$ & $111.6 \pm 7.44^{\mathrm{b}}$ & $359.20 \pm 46.45^{\mathrm{b}}$ \\
\hline $\begin{array}{l}\text { CR } 70 \% \text { ethanol fraction } \\
(89.16 \mathrm{mg} / \mathrm{kg} \mathrm{BW})\end{array}$ & $162.6 \pm 6.31^{\mathrm{ab}}$ & $670.93 \pm 62.28^{\mathrm{ab}}$ \\
\hline $\begin{array}{l}\text { CR } 70 \% \text { ethanol fraction } \\
(178.35 \mathrm{mg} / \mathrm{kg} \mathrm{BW})\end{array}$ & $147.0 \pm 9.54^{\mathrm{ab}}$ & $583.27 \pm 54.93^{\mathrm{ab}}$ \\
\hline $\begin{array}{l}\text { CR } 70 \% \text { ethanol fraction } \\
(356.7 \mathrm{mg} / \mathrm{kg} \mathrm{BW})\end{array}$ & $127.8 \pm 6.10^{b}$ & $452.07 \pm 47.10^{\mathrm{b}}$ \\
\hline $\mathrm{CMC}-\mathrm{Na}$ & $197.8 \pm 12.09^{\mathrm{a}}$ & $825.62 \pm 33.13^{\mathrm{a}}$ \\
\hline
\end{tabular}

CR ( $\overline{\text { Cyperus rotundus } \text { Rhizome }) ~}{ }^{a}$ Significantly different from diazepam $(\mathrm{p}<0.05),{ }^{\mathrm{b}}$ Significantly different from CMC-Na $(\mathrm{p}<0.05)$

Rotarod test aims to evaluate peripheral neuromuscular blockade and motor coordination (Doukkali et al., 2015). The administration of CR ethanol fraction can lead to sedation effect; therefore, the motor activity significantly decreased when compared to the negative control (Na $\mathrm{CMC}$ ). The results showed that $356.7 \mathrm{mg} / \mathrm{kg}$ CR ethanol fraction had the best anxiolytic activity and was comparable to diazepam (Table III). The results also indicated that the CR ethanol fraction had higher potential as anxiolytic when administered at a dose of $356.7 \mathrm{mg} / \mathrm{kg}$ than $500 \mathrm{mg} / \mathrm{kg}$ of CR ethanol extract (Ahmad et al., 2014).

Traditional medicine has been clinically proven to reduce anxiety and depression through the mechanism of monoamine reuptake inhibitor, such as noradrenaline, serotonin, and dopamine, and also through the GABAergic effects (Saki et al., 2014). Phytochemicals study reveals that the fraction of the $70 \%$ ethanol of Cyperus rotundus rhizome contains flavonoids, alkaloids, saponins, and tannins. The flavonoids in Cyperus rotundus rhizome consists of quercetins and myricetins (Krishna and Renu, 2013). Quercetin contained in other plants such as Tilia americana has been investigated to have the mechanism of GABAergic inhibition. The mechanisms of flavonoids from each plant may be different, depending on chemical structure and pharmacology activity, but 
anxiolytic and sedative activities typically involve a system of GABAergic and serotonergic (Aguirre-Hernández et al., 2016). Also, based on Du et al., (2002), flavonoids activity as anticonvulsants involve GABA receptor agonist

\section{CONCLUSIONS}

The ethanol fraction of Cyperus rotundus rhizome showed the highest hypnotic-sedative and anticonvulsant activities, which was comparable to the positive control. The ethanol fraction of Cyperus rotundus rhizome shortened the duration of HLE as much as sodium valproate and potentiated the phenobarbital-induced sleep by decreasing the onset and prolonging the duration of sleep. The highest dose of $70 \%$ ethanol fraction of Cyperus rotundus rhizome $(356.7 \mathrm{mg} / \mathrm{kg})$ showed the best anxiolytic activity and was comparable to diazepam ( $p>0.05$ ).

\section{REFERENCES}

Aguirre-Hernández, E., González-Trujano, M.E., Terrazas, T., Santoyo, J.H., and Guevara-Fefer, P. 2016. Anxiolytic and sedative-like effects of flavonoids from Tilia americana var. mexicana: GABAergic and serotonergic participation, Salud Mental, 39(1): 37-46.

Ahmad, M., MahayRookh, Rehman, A.B., Muhammad, N., Amber, Younus, M., and Wazir, A. 2014. Pharmacological activities of Cyperus rotundus Linn , 27(6): 2241-2246.

Ajao, M.Y., and Akindele, A.J. 2013. Anxiolytic and sedative properties of hydroethanolic extract of Telfairia occidentalis leaves in mice, Brazilian Journal of Pharmacognosy, Elsevier, 23(2): 301-309.

Arenas, M.C., Daza-Losada, M., Vidal-Infer, A., Aguilar, M.A., Miñarro, J., and Rodríguez-Arias, M. 2014. Capacity of novelty-induced locomotor activity and the hole-board test to predict sensitivity to the conditioned rewarding effects of cocaine, Physiology and Behavior. Elsevier B.V, 133: 152-160.

Biradar, S., Kangralkar, V.A., Mandavkar, Y., Thakur, M., and Chougule, N. 2010. Anti Inflammatory, Anti - Arthritic, Analgesic and Anticonvulsant Activity of Cyperus Essential Oils, 2(4): 9-12.

Brown, G.R., and Nemes, C. 2008. The exploratory behaviour of rats in the hole-board apparatus: Is head-dipping a valid measure of neophilia?, Behavioural Processes, 78(3): 442-448.

Brunton, L., Chabner, B., and Knollman, B. 2013. Goodman and Gilman's The Pharmacological Basis of Therapeutics, Journal of Chemical Information and Modeling.

Castel-Branco, M.M., Alves, G.L., Figueiredo, I.V., Falcao, A.C., and Caramona, M.M. 2009. The maximal electroshock seizure (MES) model in the preclinical assessment of potential new antiepileptic drugs, Methods and Findings in Experimental and Clinical Pharmacology, 31(2): 101.

Chouksey, D., Upmanyu, N., and Pawar, R. S. 2013. Central nervous system activity of Illicium verum fruit extracts, Asian Pacific Journal of Tropical Medicine. Hainan Medical College, 6(11): 869-875.

Doukkali, Z., Taghzouti, K., Bouidida, E.H., Nadjmouddine, M., Cherrah, Y., and Alaoui, K. 2015. Evaluation of anxiolytic activity of methanolic extract of Urtica urens in a mice model, Behavioral and Brain Functions, 11(1): 1-5.

Du, X.M., Sun, N.Y., Takizawa, N., Guo, Y.T., and Shoyama, Y. 2002. Sedative and anticonvulsant activities of goodyerin, a flavonol glycoside from Goodyera schlechtendaliana, Phytotherapy Research, 16(3): 261-263.

Katzung, B. G. and Trevor, A. 2015. Chemotherapeutic Drugs, Basic and Clinical Pharmacology.

Krishna, S., and Renu, S. 2013. Isolation and Identification of Flavonoids From Cyperus Rotundus Linn. in Vivo and in Vitro, Journal of Drug Delivery \& Therapeutics, 3(2): 109-113.

Mudium, R., and Kolasani, B. 2014. Anticonvulsant effect of hydroalcoholic seed extract of croton tiglium in rats and mice, Journal of Clinical and Diagnostic Research, 8(3): 24-26. 
Saki, K., Bahmani, M., and Rafieian-Kopaei, M. 2014. The effect of most important medicinal plants on two importnt psychiatric disorders (anxiety and depression)-a review, Asian Pacific Journal of Tropical Medicine, 7(S1): S34-S42.

Venkatanarayana, N., Basha, G., Pokala, N., Jayasree, T., John, P., and Nagesh, C. 2013. Journal of Chemical and Pharmaceutical Research, 5(9): 60-64 Research Article Evaluation of anticonvulsant activity of ethanolic extract of Zingiber officinale in Swiss albino rats, 5(9): $60-64$.

Yudistyawan, H.F. 2013. Efek ekstrak umbi rumput teki (Cyperus rotundus L) sebagai antipiretik pada tikus wistar jantan yang diinduksi vaksin DPT-Hb. Available at: http://repository.unej.ac.id/handle/123456789/3653. 
